\title{
Resenhas
}

\section{discurso 44}





\section{Les passions intellectuelles}

\section{Élisabeth Badinter}

Vol 1: Désirs de gloire (1735 - 1751) (Paris, Fayard, 2010);

Vol. 2: Exigence de dignité (1751-1762) (Id., 2010);

Volonté de pouvoir (1762-1778) (Id., 2011).

Pedro Paulo Pimenta | USP

A recente aparição da trilogia de Élisabeth Badinter em edição de bolso torna acessível ao leitor de filosofia interessado no Século das Luzes um estudo de caráter histórico que já nasceu clássico. Publicados originalmente entre 1999 e 2007, os volumes de Badinter oferecem vivo panorama de um mundo filosófico animado pelas figuras de Voltaire, Maupertuis, Buffon, Diderot, d'Alembert, Rousseau, Condillac, Turgot, e outros, hoje menos conhecidos, mas, nem por isso, menos fascinantes (como Madame de Châtelet e Malheserbes, por exemplo). A autora, que nos brindara com Émilie, Émilie, ou l'ambition féminine au XVIIIè siècle, e com o que talvez seja o retrato definitivo de Condorcet (redigido juntamente com seu marido, Robert Badinter), é uma estudiosa das mais qualificadas para a tarefa, além de ser dona de um estilo leve e ágil que cativa o leitor. Por isso, as mais de mil páginas desta obra não devem assustar, e, na verdade, podem ser percorridas sem dificuldade em relativamente pouco tempo. O livro é classificado pelos livreiros franceses na seção de história, e, de fato, não se trata de uma obra de filosofia. A apresentação de conceitos é restringida ao mínimo necessário, a exposição de doutrinas é superficial, todo e qualquer aprofundamento nesse sentido é cuidadosamente evitado. Nem por isso o estudo é frívolo, pelo contrário, reconstitui uma história importante, que teve 
muitos desdobramentos, na França e em outros países - incluindo os da América Latina, o Brasil entre eles: a ascensão do intelectual como figura pública.

A divisão em três tomos, com subtítulos cuidadosamente escolhidos - "Desejos de glória", "Exigência de dignidade", "Vontade de poder" - indica que a autora identifica, no processo cuja reconstituição é o seu objeto, uma evolução nítida e inequívoca, que corresponde, grosso modo, à luta pela supremacia da ciência newtoniana no seio da Academia de Ciências, ao triunfante despontar da Encyclopédie na paisagem das Luzes, e, por fim, à crescente autoridade dos philosophes na vida pública francesa (incluindo a administração do Estado), acompanhada da afirmação do seu prestígio em outros países da Europa. Tudo isso é contado com impressionante riqueza de detalhes, graças a minuciosa pesquisa realizada em numerosas bibliotecas e arquivos, erudição que não compromete o delineamento de uma narrativa firme que é conduzida, a cada passo, com segurança e destreza. Amparada em documentos conhecidos, habilmente combinados a farto material inédito, Badinter em nenhum instante permite ao leitor duvidar da pertinência de sua tese e da validade das provas aduzidas pela investigação.

Esses méritos não impedem que o leitor se dê conta - na passagem do volume I ao II - de que há na obra uma tensão, nem sempre bem resolvida, entre o objeto declarado e o que de fato se encontra nas páginas de Badinter. Pois, no fundo, Les passions intellectuelles é uma biografia intelectual de d'Alembert, centrada não em seu pensamento (ou nas múltiplas facetas de seu pensamento), mas sim em sua trajetória institucional, primeiro como jovem membro do partido newtoniano na Academia Real de Ciências, depois como editor, ao lado de Diderot, da Encyclopédie, finalmente como secretário da Academia de Letras. Convidado por Frederico I da Prússia a presidir a academia de ciências daquele país, D’Alembert hesita, e seguidas vezes, apesar de tentado, recusa o convite; aceita, porém, uma pensão vitalícia que 
lhe é oferecida pelo rei. Frequenta os salões, alguns diretamente ligados à corte e aos ministros, mas não chega a depender diretamente dos favores dos mais poderosos. Permanece, em suma, um savant e philosophe exemplar.

Essa trajetória aparentemente tranquila parece responder ao programa traçado por d'Alembert num panfleto de 1752 sobre a independência do homem de letras. Badinter não se furta, porém, a mostrar que a fidelidade de d'Alembert ao parâmetro de honestidade intelectual por ele mesmo estabelecido é relativa, e varia conforme as circunstâncias. É que as "paixões intelectuais" do título são, em certo sentido, as paixões do intelectual, vitimado por uma patologia tão aguda, embora sofisticada, quanto a que acomete o homem comum na perseguição dos objetivos que estabelece para si mesmo. Nesse registro, mesmo a "exigência de dignidade" do segundo volume não é tanto um imperativo moral quanto uma cobrança veemente e enfática do reconhecimento, pelo poder, da importância da ciência, das letras, da filosofia. Tal reconhecimento, os philosophes o terão ou tardiamente (como Voltaire) ou no exterior (Condillac em Parma, Maupertuis na Prússia, Diderot em Moscou). Paradoxalmente, d'Alembert talvez tenha sido o mais bem-sucedido de todos, graças ao seu gênio matemático, mas também por conta das boas relações que manteve com o fluido meio intelectual da capital francesa.

Não fossem outras qualidades, apenas esta - trazer à luz a figura desse grande filósofo - já seria suficiente para recomendar a leitura da obra de Badinter. Questão diferente é saber se d'Alembert pode ser tomado, como faz a autora, como protótipo do intelectual público no Século das Luzes. Se mesmo no caso de Voltaire, a despeito de seus apologistas, essa atribuição seria questionável, a própria Badinter fornece elementos suficientes para que o leitor desconfie dessa possibilidade a respeito de seu personagem principal. Isso sem mencionar o sabor às vezes provinciano do quadro cuidadosamente desenhado. Badinter não tem interesse algum pela vida intelectual da Inglaterra, da Itália ou da 
Prússia: apenas menciona esses lugares, como espaços longínquos e vazios, ocupados temporariamente por atores franceses. Teria interesse considerável para este estudo a delimitação das diferenças institucionais que marcam a vida intelectual em Londres e em Paris na virada do século dezessete para o dezoito, a força das Academias na França, sua debilidade na Inglaterra, a liberdade de imprensa nesta, a censura oficial naquela. Em particular no caso das Luzes alemãs, a autora poderia ter se detido na importante contribuição dos intelectuais franceses, como La Mettrie, Maupertuis, Voltaire e d'Alembert, para a consolidação da cultura newtoniana num ambiente fortemente marcado pela escola de Leibniz, indicando os desdobramentos desse verdadeiro implante filosófico tanto para o debate subsequente da Aufklärung quanto para a reação de Kant e dos românticos.

Essa perspectiva algo míope talvez explique porque Badinter, após uma excelente exposição sobre a trajetória de Turgot, emblemática das limitações intrínsecas às instituições do Antigo Regime (mas que não substitui, porém, o magistral estudo de Koselleck a respeito), não faça nenhuma sugestão sobre as profundas mudanças por que passaria a vida intelectual francesa com o advento da Revolução (quando o intelectual, que antes gravitava em torno do poder, passa a ocupá-lo, como funcionário do Estado na promoção da instrução pública). Prefere, em vez disso, bem ao sabor de certo gosto francês atual, sugerir levianamente que o intelectual das Luzes teria sido o protótipo do intelectual da quarta República - cuja origem, no entanto, já foi localizada alhures. Pois apesar de todas as aproximações possíveis, em se tratando de história, como ensinam os homens da Ilustração, as similaridades muitas vezes enganam. Entre d'Alembert e Sartre ou Foucault, há três revoluções $(1789,1830,1848,1870)$ uma restauração (1814) e três guerras $(1792,1914,1939)$, eventos com peso suficiente para instituir um verdadeiro abismo entre o mundo das Luzes e o que veio depois.

Uma passagem me pareceu especialmente memorável na 
leitura desses volumes repletos de páginas saborosas. Trata-se do capítulo "Mourir en philosophe", do vol. II. Ali, talvez para a nossa decepção, ficamos sabendo que Montesquieu, em seu leito de morte, teria aceito o sacramento dos jesuítas. Covardia de um espírito livre face a face com a morte? Não nos precipitemos; as coisas não são tão simples. Como mostra Badinter, é provável que Montesquieu tenha sido movido, em seu inesperado gesto, por consideração pela situação das damas dos salões que frequentava. Uma das mais ilustres, ao saber de sua doença, rogou-lhe para que não morresse como filósofo (isto é, como ateu), para que suas amigas não se sintam vexadas, após o evento, na boa sociedade. Diante do inevitável, por que não deixar como legado a reputação intacta de amigas queridas?

Com esse gesto ambíguo, não teria Montesquieu celebrado, ainda uma vez, a superioridade do esprit de finesse sobre o esprit de système? A timidez de Badinter em suas excursões teóricas a impede de desenvolver esse ponto e de mostrar - o que seria importante para a sua tese - a tensão entre esses dois veios da reflexão iluminista na obra e no pensamento de d'Alembert - homem de letras, acadêmico, herdeiro do espírito geométrico de Descartes, continuador de Newton, enciclopedista. Essa tensão transparece principalmente na obra-prima que é o "Discurso preliminar" da Enciclopédia, testemunho definitivo do fôlego e do rigor de d'Alembert como filósofo'.

1 Uma edição crítica das obras de d’Alembert vem sendo publicada na França pelo CNRS sob os auspícios do coletivo "Groupe d'Alembert". Até o presente momento, surgiram seis volumes com escritos matemáticos e um com o inventário da correspondência. 
